DOI: $10.19195 / 0524-4544.328 .4$

\author{
PAWEŁ WIĄZEK \\ ORCID: 0000-0002-3062-9454 \\ Uniwersytet Wrocławski \\ pawel.wiazek@uwr.edu.pl
}

\title{
Prawo karne w konstytucjach sejmu koronacyjnego z roku 1588
}

Brak króla stwarzał niepowtarzalną okazję — umożliwiał uzgodnienie postulatów pewnych reform państwowych, nie zawsze wygodnych dla monarchy, i wykorzystując zasadę si non jurabis, non regnabis ${ }^{1}$, ułatwiał jednocześnie wywarcie presji na nowym władcy oraz jego akceptację (ex post) proponowanych zmian. Przekonanie o wyjątkowości okresu bezkrólewia w realizacji dążeń stanu szlacheckiego było, jak się wydaje, szeroko rozpowszechnione ${ }^{2}$. Marszałek sejmu elekcyjnego z 1632 roku Jakub Sobieski sądził wręcz, że interregnum jest najlepszą okazją do poprawienia wszystkich praw ${ }^{3}$. Zwracano na to uwagę wcześniej, już w czasie pierwszej wolnej elekcji, twierdząc, że po wyborze króla będzie za późno na naprawienie „błędów” w Rzeczypospolitej ${ }^{4}$.

Treść uchwał licznych zjazdów skupiających szlachtę i magnaterię z poszczególnych ziem wskazuje na poczucie zagrożenia wynikające z wewnętrznego rozdarcia społeczeństwa ${ }^{5}$ (którego katalizatorem stał się konflikt między obozem

1 Jej sformułowanie przypisywane jest w polskiej tradycji hetmanowi Janowi Zborowskiemu, który w Paryżu miał skierować do Henryka Walezjusza, niechętnemu zaprzysiężeniu konfederacji warszawskiej, słowa: „Et nunc nisi id feceris, Rex in Polonia non eris!”; J. Wąsowicz, Rola polskiego modelu tolerancji religijnej dla hugenotów francuskich, „Seminare. Poszukiwania naukowe” 15, 1999, s. 331; por. W. Sobieski, Trybun ludu szlacheckiego. Pisma historyczne, Warszawa 1978, s. 258.

2 E. Opaliński, Elekcje wazowskie w Polsce. Stosunek szlachty do instytucji okresu bezkrólewia, „Kwartalnik Historyczny” 92, 1985, nr 3, s. 534.

3 A.S. Radziwiłł, Pamiętnik, t. 1, Warszawa 1980, s. 193.

4 E. Opaliński, op. cit., s. 534.

5 E. Dubas-Urwanowicz, Bezkrólewie - czas integracji czy podziałów, „Przegląd Historyczny" 85, 1994, nr 1-2, s. 36. 
Zborowskich a kanclerzem Zamoyskim), zwieńczonego podwójną elekcją i wojną domową ${ }^{6}$. Wpisane w bezkrólewie zagrożenie pokoju wewnętrznego kazało społeczeństwu szlacheckiemu wprowadzić na zjazdach konfederackich postanowienia dotyczące sądownictwa na czas bezkrólewia ${ }^{7}$, czego wyrazem stały się sejmiki i sądy kapturowe ${ }^{8}$.

Wyobrażenia o funkcjach, które miał pełnić sejm koronacyjny, były w omawianym okresie mocno utrwalone w świadomości społeczeństwa. W trakcie trwania koronacji król miał zaprzysiąc ustalone na elekcji pacta conventa, na sejmie zaś miała nastąpić ostateczna, w formie konstytucji, akceptacja zgłoszonych egzorbitancji ${ }^{9}$ i postulatów. W praktyce jednak sejm koronacyjny stawał się areną zaciętej walki politycznej o uchwalenie konstytucji dotyczących spraw w zasadzie przyjętych na sejmie elekcyjnym. Po akcie koronacji szlachta miała zadanie utrudnione, sejm koronacyjny stawał się bowiem zwykłym, to jest obradującym przy udziale trzech stanów. Tylko sejm koronacyjny 1587/1588 stwarzał zarówno posłom, jak i senatorom wyjątkową szansę ${ }^{10}$.

Decyzje dotyczące zwołania sejmu koronacyjnego podjęto na sejmie elekcyjnym 19 sierpnia 1587 roku; sejmiki odbyły się we wrześniu i w październiku ${ }^{11}$. Obrady sejmu rozpoczęły się 10 grudnia i trwały do 20 stycznia 1588 roku. Jako marszałek przewodniczył im sędzia i podstarości poznański Jan Gajewski herbu Ostoja. Kilkakrotnie odraczany akt koronacji (22 października, 11 listopada i 22 listopada) odbył się ostatecznie 28 grudnia. Przyjęte przez sejm konstytucje uchwalono w atmosferze głębokich napięć politycznych okresu interregnum, w klimacie nieufności do obranego monarchy i dążenia do ograniczenia władzy królewskiej ${ }^{12}$.

6 E. Opaliński, op. cit., s. 535.

7 E. Dubas-Urwanowicz, op. cit., s. 37.

8 Sądy kapturowe były powoływane w dawnej Polsce od czasów pierwszego bezkrólewia, czyli po śmierci Zygmunta Augusta w 1572 roku, jako sądy do spraw karnych o naruszenie bezpieczeństwa publicznego oraz o przestępstwa przeciwko państwu, w których zasiadali delegaci szlachty. Sądy te zbierały się przez czas bezkrólewia co sześć tygodni na kadencję trzytygodniową, w grodach lub gdzie wymagały okoliczności. Należały do nich sprawy o podpalenie, zabójstwa, rabunki i krzywdy; zob. Z. Gloger, Encyklopedia staropolska, t. 3, Warszawa 1902, s. 3-5. Na ten temat zob. także O. Balzer, Początki sądów kapturowych, „Ateneum. Pismo naukowe i literackie” 2, 1885.

9 W dawnej Polsce, głównie w XVII wieku, określano tym mianem wszelkie wykroczenia przeciw prawu, zwłaszcza popełnione przez króla. Spisywane były na sejmach elekcyjnych przez specjalne komisje, by sejm mógł je naprawić. Działania te wynikały z przekonania szlachty, że ustrój Rzeczypospolitej jest doskonały, a przyczyna jej słabości tkwi w złych rządach króla; od łac. extra orbitae legum (,,spoza prawa”); zob. https://encyklopedia.pwn.pl/haslo/egzorbitancje;3896776.html (dostęp: 3 lutego 2019).

10 E. Opaliński, op. cit., s. 542.

11 W. Konopczyński, Chronologia sejmów polskich 1493-1793, Kraków 1948, s. 143.

12 Volumina Constitutionum, t. 1. $1493-1549$ (dalej: VC, t. 1), oprac. S. Grodziski, I. Dwornicka, W. Uruszczak, Warszawa 1996, s. 53.

Prawo 328, 2019

(C) for this edition by CNS 
W zasadzie jednak akt koronacji nie tylko zamykał interregnum w sensie prawnym, ale również uniemożliwiał szlachcie swobodne formułowanie postulatów ${ }^{13}$.

Jedną z najważniejszych kwestii, która powstawała w związku z funkcjonowaniem sądów w okresie bezkrólewia - a był to problem stały, niezależnie od sposobu organizacji podczas ówczesnego bezkrólewia, jako kapturowych czy też nadal sądów królewskich - była egzekucja wyroków. Rozmiar nieprawości, jakie czyniono podczas bezkrólewia, wskazywał, że sprawcy czynów, w których gwałcono porządek publiczny, liczyli na daleko idącą bezkarność. Wymagało to ustosunkowania się do powstałego stanu rzeczy ${ }^{14}$.

Już w początkach bezkrólewia, niemal nazajutrz po śmierci Stefana Batorego, pojawiły się wśród szlachty głosy piętnujące brak przepisów dotyczących ścigania infamisów i banitów, nawiązujące do mankamentów będących zaszłością sięgającą czasów pierwszego bezkrólewia ${ }^{15}$. Takie stanowisko zajęła i artykułowała na przykład szlachta bełska zgromadzona na sejmiku przedsejmowym 24 grudnia 1586 roku. Przyjęła ona uchwałę, w której znalazł się przepis na mocy którego starostowie mieli obowiązek „infamisów, banitów [...] ścigać i na gardle karać”16.

Konstytucye Seymu Walnego, Koronacyi Krolewskiey, Roku Bożego 1588, które uchwalono 30 stycznia pierwszego roku panowania Zygmunta III Wazy, nie odbiegają w swym charakterze od wielu innych podobnych aktów normatywnych przedrozbiorowej Polski. Lektura ich postanowień (z punktu widzenia współczesnych założeń i technik sztuki prawotwórczej) wywołuje wrażenie całkowitego chaosu. Powoduje i potęguje je brak jakiejkolwiek myśli systematyzacyjnej oraz ogromna różnorodność poddanej regulacji materii legislacyjnej. Ustawa zawiera przepisy zarówno cywilno-, jak i karnoprawne, a nawet administracyjnoprawne i porządkowe czy ustrojowe, dotyczące spraw i ogólnokrajowych, i partykularnych, o charakterze materialno- i formalnoprawnym, w tym wiele norm mieszanych materialno-procesowych. Zamieszczone w konstytucji regulacje normują szeroki zakres spraw, od postanowień de crimine laesae Maiestatis, poprzez przepisy o kadukach, postępowaniu egzekucyjnym na Rusi i Podolu, wyborze sędziów sądów ziemskich i podkomorskich, formuły przysięgi podkomorskiej, posagu należnym siostrom, wykupie dóbr zastawnych, karnoprawnej odpowiedzialności z tyt. pomocnictwa, o zajętym bydle, biskupstwach, opactwach, o poprawie przysięgi senatorskiej, dotyczące kwarty, myt podlaskich, ceł, konfirmujące daniny

13 E. Opaliński, op. cit., s. 543.

14 D. Makiłła, Próba reformy sądownictwa powszechnego z czasów bezkrólewia po ucieczce króla Henryka Walezego (1574), „Miscellanea Historico-Iuridica” 14, 2015, z. 2, s. 49.

15 A. Pieńkowska, Zjazdy i sejmy z okresu bezkrólewia po śmierci Stefana Batorego, Pułtusk 2010, s. 64-65.

16 Kaptur betski zaraz po śmierci królewskiej uczyniony, AGAD, APP 6, s. 84-92; Oblata kaptura betskiego, Biblioteka Muzeum Narodowego im. Czartoryskich w Krakowie 2723, s. 31-33; Konfederacja województwa betskiego, Betz 31 grudnia 1586, Biblioteka Zakładu Narodowego im. Ossolińskich Polskiej Akademii Nauk we Wrocławiu 15964/II, s. 41-45.

Prawo 328, 2019

(C) for this edition by CNS 
Jerzemu Farensbekowi, kanclerzowi i hetmanowi koronnemu oraz przepisy dotyczące wielu innych jeszcze kwestii ${ }^{17}$.

Karnoprawne postanowienia stanowią stosunkowo nieliczną grupę spośród blisko stu przepisów badanej ustawy. Niewątpliwie do najważniejszych z nich należały te, które dotyczyły zbrodni obrazu majestatu, w tym wyodrębnionego w tej grupie czynów przestępstwa zdrady, jak również mężobójstwa, zranienia i okaleczenia, porwania i bezprawnego więzienia szlachcica oraz przestępstwa potwarzy. W aspekcie penalnym (związanym z sankcją karną) unormowano częściowo kwestię stosowania kary wieży dolnej ${ }^{18}$ i górnej ${ }^{19}$, kar majątkowych: główszczy-

17 Volumina Legum. Przedruk Zbioru Praw staraniem xx. pijarów w Warszawie od roku 1732 do roku 1782 wydanego, t. 1, Petersburg 1859 (dalej: VL, t. 2), s. 251-270. Treść normatywną dawnych sejmowych konstytucji zamieszczonych w dziewiętnastowiecznej pijarowskiej edycji źródeł warto czasami skonfrontować z nową edycją tych źródeł, którą stanowią przygotowane do druku przez S. Grodziskiego, I. Dwornicką i W. Uruszczaka Volumina Constitutionum, t. 2. 15501609, vol. 1. 1550-1587, Warszawa 2005 (dalej: VC, t. 2, vol. 1) oraz do dr. przygot. S. Grodziski, W. Uruszczak, Volumina Constitutionum, t. 2. 1550-1609, t. 2. 1587-1609, Warszawa 2008, (dalej: VC, t. 2, vol. 2).

$18 \mathrm{~W}$ literaturze reprezentowany jest pogląd, że instytucja ta pojawiła się dopiero w epoce nowożytnej w 1538 roku (w stosunku do mężobójców szlachty); J. Bieda, Cele i organizacja zakładów karnych w I Rzeczypospolitej, „Acta Universitatis Lodziensis. Folia Historica” 94, 2015, s. 80. W praktyce była karą pośrednią między pozbawieniem wolności a karą śmierci. Dotyczyła nie tylko sfery wolności człowieka, lecz była także sankcą cielesną; M. Czerwiec, Więzienioznawstwo. Zarys rozwoju więziennictwa, Warszawa 1958, s. 21. Odsiadującemu karę codziennie dostarczano pożywienie w postaci chleba i wodę oraz wyciągano nieczystości. Skazany mógł zabrać z sobą ubrania czy też naczynia, jednakże nie miał prawa mieć piecyka lub ustępu; L. Rabinowicz, Podstawy nauki o więziennictwie, Warszawa 1933, s. 18. Początkowo brakowało wytycznych co do charakteru tej instytucji poza ogólnym sformułowaniem, że należy ją odbywać w dole wieży. Brak zasad powodował, że starostowie pozwalali skazanym na liczne udogodnienia, jak montowanie pieców, schodów czy robienie szalunków; J. Makarewicz, Polskie prawo karne, Lwów-Warszawa 1919, s. 136. Reakcją na takie praktyki była konstytucja sejmowa z 1578 roku, nakładająca na starostów zezwalających na takie czynności kary pieniężne; J. Bieda, op. cit., s. 80. Odbywający karę w wieży dolnej byli skazani tylko na siebie: nie mieli możliwości skorzystania z pomocy lekarza czy też duchownego; M. Czerwiec, op. cit., s. 21. W dobie oświecenia niehumanitarny charakter tej kary spowodował pojawienie się postulatów jej złagodzenia. Dokonał tego najpóźniej w 1769 roku marszałek wielki koronny Stanisław Lubomirski. Z jego inicjatywy w wieży dolnej umieszczono okno, piec, toaletę i ułożono posadzkę; J. Rafacz, Dawne polskie prawo karne, część ogólna, Warszawa 1932, s. 138.

19 Ilekroć konstytucja z roku 1588 nie przewiduje wyraźnie kary wieży dolnej, należy uznać, że odwołuje się do kary wieży górnej. Ta forma odbywania kary pozbawienia wolności pojawiła się już w średniowieczu (od 1453 roku groziła szlachcicowi za przestępstwo zabójstwa, jeżeli nie zdecydował się wyjechać za granicę); J. Rafacz, op. cit., s. 135. Jej rozwój przypadł na okres nowożytny. Była szeroko stosowana jeszcze w wieku XVIII, choć pod koniec tego stulecia zaczęła zastępować ją kara więzienia; J. Bieda, op. cit., s. 79. Wymiar tej sankcji wahał się od jednej godziny do jednego roku i sześciu tygodni; L. Rabinowicz, op. cit., s. 19. Represja ta miała na celu jedynie pozbawienie wolności człowieka, a nie udręczenie ciała (jak w przypadku wieży dolnej). Wejście i wyjście z wieży górnej wiązało się z pewnymi ceremoniałami. Następowało to w obecności woźnego i dwóch świadków (szlachciców) oraz wymagało spisania protokołu; J. Makarewicz, op. cit., s. 262. Karę odbywano na własny koszt w lokalach znajdujących się nad ziemią, wyposażonymi w meble, piece

Prawo 328, 2019

(C) for this edition by CNS 
zny, nawiązki i grzywny oraz szeroko pojętego materialnego zadośćuczynienia/ odszkodowania. Wypada również zwrócić uwagę na przepisy dotyczące proskrybowanych (infamisów, wywołańców).

Postanowienia przepisu zatytułowanego de crimine laesae Maiestatis Regiae, et perduellionis ${ }^{20} \mathrm{z}$ pewnością trudno uznać za wyczerpujące $\mathrm{w}$ tej materii. Nie zawierają one bowiem katalogu przestępstw przeciwko państwu i panującemu w postaci dyspozycji określających znamiona konkretnego czynu wraz z określeniem rodzaju i wymiaru sankcji karnej przewidzianej za jego popełnienie. Ustawodawca skoncentrował się na próbie sprecyzowania pojęcia crimini laesae Maiestatis. Zakres podmiotowy ograniczono do osób stanu szlacheckiego ${ }^{21}$, natomiast zakres przedmiotowy zdefiniowano zawężająco, analogicznie jak w statucie z roku 1539, który pozwalał na uznanie za crimen laesae maiestatis czynów godzących w osobę króla ${ }^{22}$. Dyspozycja stosownego przepisu nie pozwala jednak na zbyt ścisłą, zawężającą wykładnię dogmatyczną, ograniczającą zakres karalności czynu wyłącznie do sfery werbalnej, do publicznych wypowiedzi o charakterze znieważającym; in fine mowa w nim o (przykładowo wymienionych) działaniach, które ,podług prawa” mają polegać na knowaniu i udziale w spisku przeciwko osobie króla i jego władzy ${ }^{23}$.

W praktyce życia polityczno-prawnego królowie korzystali z szerokiej formuły interpretacyjnej traktującej jako spełniające wymogi statutowej dyspozycji wszelkie w istocie czyny, które choćby pośrednio tylko godziły w majestat panującego lub za takie mogły być uznane. Szerokie ujęcie tego przestępstwa (interpretatio extensiva) pozwalało sądzić pod zarzutem popełnienia crimini laesae maiestatis osoby, których działania skierowane były bezpośrednio przeciwko

lub inne potrzebne sprzęty, które skazany przynosił z sobą. Skazany miał również prawo do własnego pożywienia, utrzymywania służącego, odwiedzin krewnych czy też korzystania z pomocy lekarza i duchownego; K. Pawlak, Za kratami więzień i drutami obozów, Kalisz 1999, s. 10.

20 „Ieśliby kiedykolwiek Nam, y Potomkom naszym Krolom Polskim, z poddanym swym, szlacheckiego zawołania, przyszła sprawa o crimen laesae Maiestatis, które tylko in personam Regiam, podług prawa, machinatione, conspiratione, violento conatu, et quod longe absit, facto ipso, in vitam committiur [...]"; ibidem; s. 251.

21 „Ieśliby kiedykolwiek Nam, y Potomkom naszym Krolom Polskim, z poddanym swym, szlacheckiego zawołania, przyszła sprawa o crimen laesae Maiestatis [...]”; ibidem.

22 „Crimen laesae Majestatis, ita postulantibus Terrarum nostrarum Nuncijs, volumus nisi in persona nostra locum habere: et non in alios, quamtumvis publicas personas gerentes, extendi. Si quod autem quempiam facinus, vel homicidium, in his fueris commissum: qui personam nostram, vel Senatoria, vel aliqua publica dignitate, loco, et Officio fungerentur: in eum secundum statutum animadvertetum [...]"; Constitutiones in Conventi Generali Cracoviensi. Anno 1539, VL, t. 1, s. 270. Rękopis znajduje się w zbiorach Zakładu Narodowego im. Ossolińskich we Wrocławiu, pod sygn. oryginału: 1048/II.

$23, \ldots[$,... machinatione, conspiratione, violento conatu, et quod longe absit, facto ipso, in vitam committiur [...]", VL, t. 2, s. 251.

Prawo 328, 2019

(C) for this edition by CNS 
senatorom, posłom ziemskim, królewskim sędziom oraz doradcom monarchy ${ }^{24}$. Dzieje szesnastowiecznej Polski znają co najmniej kilka takich przypadków, zarówno sprzed uchwalenia statutu z roku $1539^{25}$, jak i mających miejsce już po jego ogłoszeniu ${ }^{26}$. $\mathrm{Z}$ oczywistych powodów nie cieszyło się to aprobatą przedstawicieli narodu politycznego, powodując jego opór i postulaty zmiany takiego stanu rzeczy, wyrażone choćby w sformułowanej na sejmie w roku 1550 prośbie posłów szlacheckich, ,aby wedle statutu z 1539 r. crimen laesae majestatis nie był rozumian i używan jedno o samej osobie JKMci"27. Ostatecznie do zamieszczenia w tekście eksplorowanej ustawy omawianego przepisu bezpośrednio przyczyniła się niewątpliwie „sprawa Zborowskich”: stracenie Samuela w 1584 roku i wytoczenie procesu jego bratu Krzysztofowi w marcu następnego roku, które to wydarzenia odbiły się szerokim echem w całej ówczesnej Rzeczypospolitej. Efektem powszechnego oburzenia szlachty stały się w konsekwencji stosowne postanowienia konstytucji sejmu koronacyjnego z roku 1588, która ponownie expressis verbis ograniczała pojęcie zbrodni obrazy majestatu do czynów skierowanych bezpośrednio przeciwko osobie panującego ${ }^{28}$. Ratio legis przyjętych regulacji nietrudno wskazać, nie sposób bowiem podważyć poglądów i opinii wskazujących na pogłębiające się powszechnie obawy korzystającej z licznych swobód i wolności szlachty o dążenie władzy królewskiej do zaprowadzenia $a b$ solutum dominium.

Spośród czynów objętych wspólnym mianem zbrodni obrazy królewskiego majestatu, wyraźnie wyodrębnia konstytucja sejmowa przestępstwo zdrady, czemu daje wyraz już w tytule stosownego przepisu ${ }^{29}$. Dokonane w konstytucji

24 M. Dyjakowska, Crimen laesae maiestatis jako przykład wpływów prawa rzymskiego na prawo Polski przedrozbiorowej. Stan badań i postulaty, [w:] Współczesna romanistyka prawnicza w Polsce, red. A. Dębiński, M. Wójcik, Lublin 2004, s. 74.

25 Przykładem takich praktyk był na przykład w roku 1507 proces o zabójstwo sędziego grodzkiego, w którym skazano jednego z oskarżonych, czy też proces kasztelana sądeckiego Stanisława Szafrańca, sądzonego w 1527 roku propter contradictionem laudorum communium in conventione Bitgostiendi co, jak uznano, naruszało również dostojeństwo króla; A. Lityński, Przestępstwa polityczne w polskim prawie karnym XVI-XVIII wieku, Katowice 1976, s. 20. Analogiczny charakter miał proces kasztelana biechowskiego Mikołaja Rusockiego, oskarżonego o zbrodnię obrazy majestatu w procesie przed sądem sejmowym w marcu 1538 roku, w którym sądzono go o zabójstwo kasztelana brzeskiego Tomasza Lubrańskiego; M. Dyjakowska, Crimen laesae maiestatis. Studium nad wplywami prawa rzymskiego w dawnej Polsce, Lublin 2010, s. 66.

26 Dowodzi tego proces Jana Sapiehy z 1541 roku o obrazę majestatu, za oczernianie królowej przez rozsiewanie pogłosek o dążeniu Bony do wygubienia magnatów, czy też proces Stanisława Tarnowskiego z 1570 roku, za zbrojne odebranie Tarnowa Ostrogskim i spustoszenie okolic na czele oddziału zbrojnych; A. Lityński, op. cit., s. 21.

\section{Ibidem.}

28 „Ieśliby [...] przyszła sprawa o crimen laesae Maiestatis, które tylko in personam Regiam, podług prawa [...]", machinatione, conspiratione, violento conatu, et quod longe absit, facto ipso, in vitam committiur [...], VL, t. 2, s. 251.

29 De crimine laesae Maiestatis Regiae, et perduellionis; VL, t. 2, s. 251.

Prawo 328, 2019

(C) for this edition by CNS 
z 1588 roku przedmiotowe ograniczenie zakresu zbrodni obrazy majestatu do osoby monarchy oznaczało wyodrębnienie zdrady w sposób negatywny ${ }^{30}$.

Nieco precyzyjniej i obszerniej niż w przypadku crimini laesae Maiestatis ustawa określiła działania, jakie (w myśl jej postanowień) mają podlegać odpowiedzialności karnej z tytułu popełnionej zdrady. Do czynów uznanych za wypełniające znamiona perduellionis contra R.P. zaliczała bunty w porozumieniu z nieprzyjacielem, zdradzanie nieprzyjacielowi tajemnic państwowych, poddanie zamku w zmowie z nieprzyjacielem, zdradzanie nieprzyjacielowi tajemnic państwowych, naruszenie przymierza międzynarodowego, jak też jakiegokolwiek rodzaju występek „contra Rempublicam”31. Istotę znaczenia tej regulacji, a jednocześnie kryterium dokonanego ustawowo w szesnastowiecznym prawie polskim wyodrębnienia zdrady z ogólnej konstrukcji crimini laesae maiestatis było to, że perduellio „,nono contra principiom directe, sed contra ipsum et Rempublicam” jest wymierzone ${ }^{32}$.

Kompromis między interesami dworu królewskiego i narodu politycznego został w ten sposób osiągnięty, umożliwiając panującemu, wobec takiego kształtu przyjętych regulacji prawnych, wytaczanie w sprzyjających okolicznościach procesów przeciwnikom politycznym dworu, zajmującym nieusuwalne urzędy i stanowiska. Przyjęte w konstytucji sejmu koronacyjnego postanowienia okazały się wyjątkowo trwałe i przetrwały w takim kształcie aż do czasów Sejmu Wielkiego $^{33}$.

Omawiany przepis de crimine... ustawy z roku 1588 zawiera również postanowienia dotyczące odpowiedzialności karnej za popełnienie przestępstwa potwarzy (zniewagi/zniesławienia) wobec osoby niesłusznie oskarżonej o zbrodnię obrazy majestatu, przy czym konstytucja sejmu koronacyjnego odsyła w tym przypadku do konstytucji sejmu piotrkowskiego z 1565 roku $^{34}$. Przewiduje ona orzeczenie kumulatywnie kary pieniężnej (w wysokości 100 grzywien) oraz kary pozbawienia wolności (w wymiarze 12 tygodni przymusowego przebywania w wieży dolnej ${ }^{35}$ ) wobec sprawcy takiej potwarzy, który bezpodstawnie naruszyłby w takim przypadku cześć i honor szlachcica podobnym zarzutem, narażającym znieważonego na surową odpowiedzialność karną ${ }^{36}$. Stosowny przepis konstytucji sejmu koronacyjnego wieńczy jednak istotne uzupełnienie, ostatecznie

30 M. Dyjakowska, Subsydiarne stosowanie prawa rzymskiego w Polsce przedrozbiorowej na przykładzie zbrodni obrazy majestatu, „Teka Komisji Prawniczej OL PAN” 5, 2012, s. 65.

31 VL, t. 2, s. 252.

32 M. Zalaszowski, Ius Regni Poloniae, t. 1-2, Poznań 1701-1702, s. 711.

33 Por. A. Lityński, op. cit., s. 54.

34 „A ieśliby się to pokazało, izby pozwany [o zbrodnie obrazy majestatu — P.W.] niewinnie a potwarnie był odniesion, ma bydź delator nobilis, sive comparueit sive non, karan wedle konstytucyi, na takie anno 1565 uchwaloney"; VL, t. 2, s. 252.

35 Konstytucje Sejmu Piotrkowskiego 1565 roku; VC, t. 2, vol. 1, s. 162-178.

36, ,...] a gdzieby się nalazło [...], iż citatus niewinnie a potwarznie pozwan był: wtedy on aktor będzie mu powinien [...] sto grzywien winy położyć [...]. Y ktemu jeszcze dwanaście niedziel 
brzmi on bowiem: „[...] karan wedle konstytucyi, anno 1565 uchwaloney, a na tym seymie poprawioney, a plebeius poena capitis". Wątpliwości może budzić to, czy zwykła kara śmierci ma mieć charakter względnej, czy bezwzględnej sankcji karnej; czy miała zastąpić kary przewidziane w konstytucji piotrkowskiej, czy być jedynie uzupełnieniem postanowień ustawy, do której odsyła, nadając karze śmierci charakter fakultatywny.

Jeżeli jednak w procesie dowodzenia własnej niewinności oskarżony o zbrodnię obrazy majestatu opierałby się wyłącznie na własnej przysiędze, wówczas delator winien być zwolniony od wszelkiej odpowiedzialności karnej z tytułu stawianego mu zarzutu ${ }^{37}$.

Przyjęte regulacje stanowią pewne novum wobec dotychczasowych tradycji prawa ziemskiego o zwyczajowej proweniencji, opartych częściowo na późnośredniowiecznych statutach, które przewidywały w podobnych przypadkach kary pieniężne oraz karę „odszczekania” obelżywych lub zniesławiających słów ${ }^{38}$. Wydają się one bliższe nowym tendencjom, jakie pojawiły się w szesnastowiecznym ustawodawstwie zmierzającym do zaostrzenia represji karnej poprzez zagrożenie karą śmierci sprawcom podobnych czynów ${ }^{39}$.

Do karnoprawnych instytucji prawa ziemskiego uregulowanych w konstytucjach sejmu koronacyjnego należy tak zwana odpowiedź. Jej istotą było stworzenie ram prawnych działań odwetowych o charakterze samopomocy, dopuszczalnych i stosowanych pierwotnie w nieograniczonym zakresie; „ucywilizowanie” prawa do zemsty za wyrządzoną krzywdę.

U schyłku średniowiecza zaczął przyjmować się zwyczaj, że zemsta powinna być wprzódy zapowiedziana; zwało się to „odpowiedzią”. Odpowiedź powinna być dana ,przystojnie, wedle obyczaju rycerskiego ${ }^{40}$ ". Jeśli ktoś w wyniku wyrządzonej mu krzywdy przez kogoś innego był wedle ówczesnych wyobrażeń uprawnionym do wykonania prawa zemsty, musiał tę zemstę uprzednio przeciwnikowi „zapowiedzieć”, ustnie lub (z czasem) pisemnie (poprzez tak zwane listy odpowied-

na dnie w wieży siedzieć ma”; Konstytucye seymu piotrkowskiego, 1565 („O rzeczach, które się poczciwości dotyczą"); VL, t. 2, s. 53.

37 ,iednak gdzieby obwiniony nie zgoła, ale przez przysięgę się odwiodł, tedy na delatora żadna poena ściągać się nie ma; VL, t. 2, s. 252.

$38 \mathrm{~W}$ razie nieudowodnienia przynoszącego ujmę na czci zarzutu, sprawca winien swoje słowa „odszczekać jak pies pod ławą”; I. Zgoliński, Zniesławienie w polskim prawie karnym. Zagadnienia teorii i praktyki, Warszawa 2013, s. 37.

39 I statut litewski z roku 1529 w art. VII przewidywał karę śmierci dla osoby, która raniła lub lżyła posła królewskiego; ibidem. Wydany przez Zygmunta Starego w 1537 roku specjalny statut poświęcony upowszechniającemu się zjawisku dyfamacji dokonywanej za pomocą druku przewidywał w pewnych przypadkach karę śmierci dla osób publikujących obelżywe pisma zwane paszkwilami; ibidem, s. 38.

$40 \mathrm{~W}$ nauce panuje powszechnie akceptowane przekonanie, że było to naśladowanie obcych zwyczajów, przejętych z rycerskiego świata zachodniej Europy. Przez wysłanie odpowiedzi wysyłający ją „ogradzał swoją cześć”; S. Kutrzeba, Dawne polskie prawo sądowe w zarysie, Lwów-Warszawa-Kraków 1927, s. 9-10. 
nie). Odpowiadający zawiadamiał tego, któremu posyłał odpowiedź, że ma się go strzec wszędzie, że będzie on się starał pozbawić go życia. Niekiedy odpowiadający ograniczał treść zemsty, na przykład zapewniając, że nie będzie zemsty wykonywał $\mathrm{w}$ domu tego, któremu odpowiada ${ }^{41}$. Zadanie śmierci bez odpowiedzi, a więc podstępnie, ukradkiem, uważano za rzecz podłą, niegodną szlachcica i rycerza ${ }^{42}$. Karane było ono gardłem, jeśli jednak zadano je po uprzedniej odpowiedzi — karą wieży ${ }^{43}$.

Dopiero konstytucja z 1588 roku unormowała prawnie formę odpowiedzi, stanowiąc, że odpowiedzialność prawna osoby, która w poczuciu krzywdy podjęłaby wobec sprawcy działania odwetowe, powinna zostać ograniczona do kary stu grzywien, o ile zemsta została przez niego poprawnie zapowiedziana (czyli zgodnie z ustawowo sprecyzowanymi zasadami) ${ }^{44}$. By uniknąć postępowania karnego i kar kryminalnych, odpowiadający zobowiązany był spełnić przewidziane dla poprawności tej instytucji wymogi proceduralne. Odpowiedź miała być przesłana przez dwu ze szlachty oraz podana do oblaty w grodzie powiatu, w którym mieszkał ten, komu posyłano odpowiedź. Zapowiedzianą zemstę można było realizować dopiero po upływie sześciu tygodni od złożenia odpowiedzi ${ }^{45}$.

Honor, godność i cześć rycerska stanowiły w szlacheckiej społeczności i dawnym polskim prawie ziemskim wartości cenione wyjątkowo wysoko i od początku polskiej państwowości podlegające szczególnej ochronie prawnej. W ciągu wieków rozwoju państwa i prawa tendencje te nie tylko się utrzymywały, lecz nawet umacniały. Godzące w te wartości przestępstwa uznawano za najcięższe, a przewidziane za ich popełnienie sankcje karne były wyjątkowo surowe i dolegliwe dla sprawców. Najcięższy ze zniesławiających zarzutów - o pochodzeniu szlachcica z nieprawego łoża - traktowany był na równi z mężobójstwem i tak samo był karany ${ }^{46}$. Jeden z najwybitniejszych polskich historyków i prawników epoki oświecenia Teodor Ostrowski twierdził, że:

\section{Ibidem.}

42 P. Dąbkowski, Zasada jawności w dawnem prawie polskiem, „Przewodnik Historyczno-Prawny" 5, 1937, s. 11-12.

43 Ibidem. Zob. także P.R. Dąbkowski, Jeszcze o odpowiedzi w prawie polskiem, Lwów 1899.

44, ,...] aby każdy spokoynie żył, ani się swych krzywd privata authoritate mścił, ale prawem pospolitym się kontentował: przeto ustawiamy, gdyby kto szlachcicowi sobie równemu odpowiedź posłał, a byłby o to legitime convictus i ma bydź na zapłacenie szkód, iako aktor poprzysięże, cum poena centum marcarum skazan"; VL, t. 2, s. 254-255.

45 „A gdyby kto będąc pozwany criminaliter bronić się chciał odpowiedzią, którą by ante crimen miał posłać: tedy się inakszą bronić nie może, iedno taką, ktorąby przez Woźnego y dwu szlachcicow uczynił: y onę dał do ksiąg onego Grodu, pod ktorymby mieszkał ten, komu odpowiedział, wpisać personaliter: a po wpisaniu do akt odpowiedzi takowey nie ma przeciwko stronie on odpowiednik nic violentum poczynać do sześci niedziel. Alioquin, gdyby się odpowiednik tak nie zachował, tedy mu odpowiedź takowa nie ma iść, ad defensionem criminis. W czym też scrutinium respectu temporis, z pilnością odprawiać się ma"; ibidem.

46 Z. Naworski, Dobra sława i cześć w aktach sadowych dawnej polski, [w:] Honor, cześć, godność. Aspekty historyczno-prawne, red. P. Wiązek, Wrocław 2016, s. 85. 
obraza honoru i sławy cudzey wyrównywa prawie zamachom na życie ludzkie czynionym; w rzędzie przestępstw niniejszych kłaść się może potwarz lub kalumnia. Występku tego dopuszcza się ten, kto bez pewnych i dowodnych fundamentów, jakikolwiek kryminał drugiemu zarzuca i nie dowodzi ${ }^{47}$.

Tradycje szczególnego stosunku do czci rycerskiej i wagi jej prawnej ochrony w pełni zdają się potwierdzać konstytucje sejmu koronacyjnego z 1588 roku. Regulacje prawne poświęcone przestępstwu zniewagi zamieszczono nie tylko w postanowieniach „de crimine laesae Maiestatis Regiae, et perduellionis”, ale również $\mathrm{w}$ przepisie „O rzeczach, które się poczciwości dotyczą"48. Treść obu regulacji jest bardzo podobna co do meritum. Oba przepisy odsyłają do tej samej konstytucji sejmu piotrkowskiego z 1565 roku, oba również przewidują bezkarność sprawcy potwarzy, jeżeli w toku postępowania w procesie, którego przedmiotem był stawiany spotwarzonemu zarzut, pozwany ten ograniczył obronę jedynie do złożenia przysięgi.

Zasadnicza różnica między tymi przepisami tkwi jednak w sferze sankcji. Stanowiące lex specialis postanowienia o karalności potwarzy zarzucającej spotwarzonemu popełnienie zbrodni obrazy królewskiego majestatu bądź zdrady przewidują stosowanie w takim przypadku kary śmierci, podczas gdy w pozostałych przypadkach potwarzy ustawodawca podwyższał obowiązującą na mocy konstytucji z 1565 roku karę grzywny do jej dwukrotności (czyli z dotychczasowych stu do dwustu grzywien srebra), pozostawiając w mocy niezmienione przepisy dotyczące kary wieży oraz obowiązku wynagrodzenia szkód.

Wśród karnoprawnych postanowień konstytucji sejmu koronacyjnego znalazły się przepisy penalizujące pojedynek. Jako instytucja prawna pojawił się on w średniowiecznej Polsce najpewniej za wzorami przejętymi z Europy Zachodniej. Pierwotnie jako pojedynek sądowy miał on charakter instytucji formalnoprocesowej, będąc jedną $\mathrm{z}$ form sądu bożego w postępowaniu dowodowym w procesach akuzacyjnych. Pod koniec wieków średnich, najpóźniej w XIV-XV stuleciu, pojedynek przestał pełnić dotychczasową funkcję, stając się elementem eposu rycerskiego jako środek mający bronić honoru i czci szlacheckiej. Negatywne konsekwencje jego rozwoju w życiu społecznym, prawnym i politycznym stosunkowo wcześnie zaczęły skłaniać legislatorów do penalizowania tego zjawiska, przy czym tendencja ta miała charakter ogólnoeuropejski ${ }^{49}$.

47 T. Ostrowski, Prawo cywilne narodu polskiego, t. 1, cz. 4. O przestepstwach i karach, Warszawa 1787, s. 349-350.

48 Stanowi on, że ,winę pieniężną konstytucyi anni 1565 o rzeczach, które się poczciwości dotyczą, przeciw tym, którzy by niewinnie potwarnie pozywali podwyższamy na dwieście grzywien [...] z siedzeniem w wieży y nagrodą szkod wedle tamtey konstytucyi, z tą deklaracyą: iż gdyby pozwany przez przysięgę crimen objectum dekretem naszym zbył, taka wina na aktorze nie ma być skazowana"; VL, t. 2, s. 256-257.

49 Najwcześniej bodaj w Europie świeckie władze państwowe zaczęły ustawowo penalizować pojedynek u schyłku pierwszej połowy XVI wieku (Wenecja i Mediolan uczyniły to w roku 1541). We Francji pierwszy królewski ordonans przeciwko pojedynkom pojawił się w roku 1566 . Nieco 
Spowodowało to wreszcie reakcję władz państwa polskiego, które pod groźbą wysokich sankcji karnych zabroniły pojedynkowania się. Stosowne regulacje zamieszczono w postanowieniach konstytucji z 1588 roku, która jako pierwsza w Polsce, powołując się na sprzeczność z prawem chrześcijańskim ${ }^{50}$, zakazała pojedynków w postanowieniach de duellis ${ }^{51}$.

$\mathrm{W}$ istocie rzeczy omawiane regulacje wyodrębniają dwa rodzaje pojedynków, z których jeden tylko podlega sankcjom karnym, a zależy to od uprzedniej wiedzy i zgody króla na odbycie zbrojnej konfrontacji. Samo wyzwanie na pojedynek, jak również przyjęcie wyzwania skutkuje karą pieniężną w wysokości 60 grzywien oraz kumulatywnie karą pozbawienia wolności w wysokości półrocznego pobytu w wieży. Jeżeli monarcha wyraził zgodę na pojedynek, uczestnicy nie mieli ponosić żadnej kary. Zasada, w myśl której zezwolenie króla zwalnia od skutków represji karnej, która ukształtowała się już u schyłku średniowiecza, nie była zasadniczo kwestionowana w XV i XVI wieku. Została usankcjonowana postanowieniami konstytucji sejmu koronacyjnego i pozostała niezmieniona aż do upadku Rzeczypospolitej. W istocie stanowiła ona martwy przepis, w praktyce bowiem władcy z niego nie korzystali. W XVI wieku miał miejsce tylko jeden taki przypadek, za panowania Zygmunta Starego w 1511 roku. Z XVII i XVIII wieku nie zachowały sią żadne informacje, by taka sytuacja miała miejsce.

Wypada zwrócić uwagę, że przewidziana w konstytucji odpowiedzialność karna dotyczy jedynie osób, które podjęłyby formalne, wiążące kroki zmierzające do odbycia pojedynku bez uprzedniej zgody króla. Karalne było więc samo wezwanie do pojedynku oraz przyjęcie wyzwania. Ustawa milczy natomiast na temat tego, jaką karę ma ponieść ten, który zrani lub zabije w pojedynku swego przeciwnika. Wydaje się, iż należy wnosić, że odpowiada on wówczas za rany lub mężobójstwo tak, jak gdyby tych przestępstw dopuścił się w innych warunkach. Wyznaczone więc w konstytucji kary przewidziano za samo tylko wyzwanie i za stawienie się na takie wyzwanie.

później stosowne ustawodawstwo pojawiło się w Niemczech (najstarszy z tak zwanych Duellverbote miał ogłosić cesarz Maciej w roku 1617); S. Kutrzeba, Pojedynki w Polsce, Kraków 1909, s. $42-43$.

50 Analogicznie jak było to z sądami bożymi u progu XIII wieku, tak i w tej nowej rzeczywistości początków czasów nowożytnych jako pierwszy wystąpił przeciw pojedynkowi Kościół. Już papież Juliusz II wydał w 1509 roku bullę Regis pcicifici, w której zagroził pojedynkującym się klątwą i odmową chrześcijańskiego pogrzebu, a książętom, którzy udzielą miejsca na pojedynek nie tylko klątwą, lecz także karą pieniężną i utratą lenna. Stanowisko papieskie kontynuowane było konsekwentnie w kolejnych dziesięcioleciach.

51 „Iż się to między ludźmi rozbieżało, że ieden drugiego na pojedynek wyzywał, nad prawo chrześcijańskie: tedy uchwalamy, aby żaden szlachcic szlachcica na duellum nie wyzywał: a wyzywany aby się nie stawił, oprócz, żeby komu przez Nas dopuszczono. A ktoby się przeciw temu postanowieniu ważył tego uczynić, tedy ma siedzieć puł roka w wieży, y sześćdziesiąt grzywien dać, o co forum w Ziemstwie"; VL, t. 2, s. 255. 
Rzeczywistość prawna wobec formalnie zakazanego pojedynku odbiegała jednak dość dalece od normatywnych regulacji z 1588 roku. Bijatyki zwłaszcza w XVII i XVIII wieku były na porządku dziennym, szczególnie wśród żołnierzy i sytuacja ta nie zmieniła się z biegiem czasu, wprost przeciwnie. Do nielicznych należały próby podejmowane na rzecz stanowczego przestrzegania prawa ${ }^{52}$, sytuacja pod tym względem zdecydowanie nie ulegała zmianie. Stopniowo pojedynki stawały się formalnością dla uczynienia zadość zwyczajowi i presji środowiskowej ${ }^{53}$.

W XVI wieku jednym z największych wyzwań, jakie stanęły przed polityką kryminalną państwa, stało się stworzenie skutecznych instrumentów i podjęcie efektywnych działań mających powstrzymać plagę zabójstw i morderstw. Z inicjatywą zaostrzenia represji przeciw mężobójcom wystąpił wobec króla sejm piotrkowski z 1510 roku. Powodem była wzrastająca liczba zabójstw, zarówno rozmyślnych, jak i notorycznych (homicidia volontaria et notoria), które pozostawały bezkarne. W księgach sądowych, począwszy od XVI wieku, mnożą się sprawy o zabójstwa, zwłaszcza w obrębie samej społeczności ziemiańsko-szlacheckiej ${ }^{54}$. Odnaleziony przez T. Czackiego „regestr zabójstw i złodziejstw” za lata 1507-1509 świadczy o tym, że mężobójstw dokonywano wówczas w Polsce wielokrotnie więcej niż współcześnie, a rzeczywista ich liczba była zapewne jeszcze większa, niż wynikałoby to z regestru ${ }^{55}$.

Wśród szlachty coraz bardziej zaczęto akceptować potrzebę zaostrzenia prawa wobec mężobójców. Postulaty te zyskały przychylność monarchy, czego efektem stało się przyjęcie na sejmie w 1510 roku konstytucji niemal rewolucjonizującej dotychczasowe prawo karne - ścigania z urzędu podejrzanych o zabójstwa $\mathrm{w}$ miejsce dotychczasowej zasady ścigania takich zbrodni wyłącznie z inicjatywy krewnych poszkodowanego. Sprawy takie miał sądzić sąd króla na podstawie doniesienia o przestępstwie, do czego zobowiązywano starostów, grożąc im za niedopełnienie tego obowiązku karą majątkową w wysokości 100 grzywien lub utratą urzędu. Ustawa miała obowiązywać w tym kształcie pięć lat ${ }^{56}$, po czym miała tracić swoją moc obowiązującą, przywracając stan prawny ante

$52 \mathrm{~W}$ artykułach marszałkowskich, zatwierdzonych przez sejm 1679 r., znalazł się surowy zakaz, aby nikt ,[...] nie miał, ani się ważył in duellum drugiego wyzywać, a gdyby się tego dopuścił, miał być , ,...] in recenti facto et crimine sine ullis exceptionibus" przez urząd marszałkowski; S. Kutrzeba, Pojedynki..., s. 46.

53 Ibidem, s. 52.

54 A. Pawiński, O pojednaniu w zabójstwie wedtug dawnego prawa polskiego, Warszawa 1884, s. 65.

55 J. Widacki, Szkice z dziejów prawa karnego i kryminologii w Krakowie myśli i ludzie, Kraków 2014, s. 14-15.

56 Konstytucja sejmu piotrkowskiego z 22 lutego 1510 roki (Actum Piotrcoviae in conventu generali regni, 22 Februarii a. 1510), Corpus Iuris Polonici, sec. 1, vol. 3. Annos 1506-1522 [dalej: CIP], wyd. O. Balzer, Kraków 1906, s. 104-118. 
anno $1510^{57}$. W rzeczywistości stosowano ją po upływie tego okresu, co najmniej jeszcze w drugiej połowie XVI wieku ${ }^{58}$. Niemal cały wiek XVI w dziejach prawa polskiego upłynął na rywalizowaniu publiczno- i prywatnoprawnej zasady ścigania zabójców i morderców oraz na próbach osiągnięcia w tej sprawie kompromisu. Stopniowo jednak coraz wyraźniej umacniał się sentyment do tradycyjnych reguł i prywatnoprawnego sposobu ścigania mężobójstw z nielicznymi wyjątkami na rzecz zasady przeciwnej ${ }^{59}$. Potwierdzeniem tych regresyjnych tendencji stały się postanowienia konstytucji sejmu koronacyjnego z 1588 roku.

Zamieszczono je w obszernym przepisie zatytułowanym „O mężoboycach, y skrutyniach, y wieży". Jako zasadę przyjęto, że dochodzenie mężobójstwa jest sprawą pokrzywdzonych, czyli rodziny. Chodziło jednak o to, by skarga została wytoczona, a zbrodniarz nie uniknął odpowiedzialności karnej, do czego na wstępie expressis verbis nawiązuje obszerny passus ${ }^{60}$. W rzeczywistości bowiem na różnorodne sposoby obchodzono przepisy uprawniające lub zobowiązujące do wszczęcia postępowania i ukarania sprawcy. Konstytucja sejmowa podwajała wysokość kary pieniężnej, stosowanej dotąd wobec mężobójców, ze 120 grzywien do 240 , a w przypadku gdyby czynu dokonano przy użyciu broni palnej, ustanawiała karę w wysokości 480 grzywien ${ }^{61}$. Wobec mężobójcy unikającego odbycia publicznej kary wieży przewidziano karę infamii ${ }^{62}$. Ponadto ustawa sejmu koronacyjnego obligowała uprawnionego do wniesienia skargi i podjęcia (w ciągu jednego roku) działań zmierzających do bezwzględnego wyegzekwowania przysługującego mu roszczenia, pod groźbą surowej sankcji karnej. W przeciwnym bowiem przypadku przewidywała ona nałożenie na niego kary takiego rodzaju i w takim wymiarze, jaką miano stosować wobec mężobójcy ${ }^{63}$. Gdyby mimo to

57 S. Kutrzeba, Mężobójstwo w prawie polskiem w XVI stuleciu, Kraków 1929, s. 6-7.

58 Por. K. Łopatecki, Organizacja, prawo i dyscyplina w polskim i litewskim pospolitym ruszeniu, Białystok 2018, s. 473.

59 Postanowienia konstytucji sejmu bydgoskiego z roku 1520 (Decreta conventus generalis regni, 4 Decembris a. 1520), CIP, s. 603-611.

60 „Iż statuty przeciw mężoboycom uczynione, do tych czasow w exekwucyą nie przychodziły, dla czego mordercom zabieżeć się nie mogło: bo ci ktorzy mieli popierać nagłownika, y konwikcyą głowy czynić iednali się, y głowę zaiednawszy, abo kogo innego w relacyi, a drudzy zmyśloną osobę na zmowie mianowali: albo w procesie sądowym tak folgowali, że głownicy win prawem opisanych uchodzili. Co iż iest przeciw prawu, które takiego iednania broni [...]”; VL, t. 2, s. 255.

61 „A żeby się ludzie tym więcey od mężoboystwa hamowali, opatrzywszy to, aby eam poenam publicam nikt nie uchodził, podwyższamy zapłacenie pieniężne głowy szlacheckey ad duplam: to iest, głowę zabitą bronią ręczną na dwieście y czterdzieści grzywien: a z rusznice na cztery sta y osiemdziesiąt grzywien"; ibidem.

62 „A ktoby będąc convictus, do wieże czasu naznaczonego nie siadł abo potem z niey wyszedł nie wysiedziawszy ma być infamis ipso facto, vigore praesentis statuti, ktory [...] ma być imany i na gardle karany, y dobra iego equivalentia poenae, mają bydź podane stronie obrażoney, aż do zapłaty głowy per successores jurevicti [...]"; ibidem.

63 „A ktoby głowę zabitą, pokrywając siedzenie w wieży zaiednał: mają obadwa, tak mężoboyca, iako y takowy przyjaciel zabitego, winą wyższey opisaną, na mężoboycę uczynioną, być karani [...]"; ibidem. 
nie spełnił on swojego obowiązku, przechodził na dalszych krewnych, a gdyby i oni nie podjęli stosowanych działań, wszczęcie postępowania w sprawie o mężobójstwo miało należeć do obowiązków urzędnika państwowego ${ }^{64}$. Utrzymano wyjątek wprowadzony w 1520 roku konstytucją bydgoską, dotyczący sejmów i sejmików. Konstytucja nałożyła także, pod groźbą kary pieniężnej w wysokości 100 grzywien, obowiązek składania zeznań w sprawie o mężobójstwo wszystkim świadkom feralnego zdarzenia w przypadku popełnienia przestępstwa w miejscu publicznym $^{65}$. Niejako przy okazji w tym samym przepisie sprecyzowano i ujednolicono nieco warunki wykonywania kary wieży dolnej przewidzianej jako kara publiczna dla mężobójców. Postanowiono, że ma być ona odbywana na głębokości 12 łokci66.

Do najcięższych przestępstw od najdawniejszych czasów po współczesność zaliczane są czyny skierowane przeciwko zdrowiu, zwłaszcza fizycznemu. To naturalne i oczywiste, albowiem za podstawową wartość niezależnie od epoki powszechnie uznawane było i jest, oprócz życia człowieka, właśnie jego zdrowie. Trudno wobec tego dziwić się temu, że w akcie normatywnym, choćby tylko w ograniczonym zakresie regulującym najważniejsze kwestie prawnokarne, zamieszczono również pewne postanowienia dotyczące karalności czynów naruszających to właśnie dobro prawne. Przepis zatytułowany „O ranach szlacheckich" wyodrębnia rany krwawe obliczne ${ }^{67}$, krwawe ${ }^{68}$ oraz sine $e^{69}$, przewidując za ich spowodowanie nałożenie na sprawcę kar majątkowych, odpowied-

64 „A gdzieby y tych nie było, abo na nich schodziło: tedy Urząd Grodzki na Trybunale o wieżę czynić powinien"; ibidem, s. 256.

65 „Ale w mieście, we wsi, przy domu, gdzie ludzie chodzą, także w przeźrzystym polu, gdy kto z rusznice zabiie, alegatio casus iść mu nie ma. [...] każdy, ktoby [...] był pozwan do oddania świadectwa in scrutinio [...] a przysięgę abo uczynić, abo ieśliby też niechciał przysiądz pod wiarą a sumnieniem prawdę powiedzieć był powinien: ktemu y poddane pan ich, ieśliby był pozwany, do scrutinium stawić ma, pod winą sta grzywien, którą [...] sąd zarazem ma na tym skazać, który by był contumax: i abo świadczyć sam, abo poddanych stawić niechciał, cum remissione ad loci Capiteneum, pro exequutione facien [...]"; ibidem.

66 „To też opatrujemy [...] iakoby nie były siedzenia sroższe w iednych niż w drugich, aby wieże na głowniki [...] wszędy od okna, ktorym wpuszczają do wieże, namniey na dwanaście łokci w głąb iednako były [...]"; ibidem, s. 255-256. Dwanaście łokci, o których mowa w ustawie, to zapewne około $7 \mathrm{~m}$, choć S. Wałęga stwierdza, że było to $9 \mathrm{~m}$; idem, System penitencjarny w dawnym Toruniu (do końca XVIII w.), „Rocznik Toruński” 17, 1986, s. 223. Tradycyjna europejska miara łokcia nawiązywała do średniej długości ręki od stawu łokciowego do końca palca środkowego. Łokieć dzielił się najczęściej na 2 stopy albo 24 cale. Jego rzeczywista długość zależała jednak od państwa, regionu i epoki historycznej. Tak zwany łokieć krakowski w połowie XVI wieku był równy 58,6 cm; https://pl.wikipedia.org/wiki/\%C5\%81okie\%C4\%87_(miara) (dostęp: 23 maja 2019); http://encyklopedia.naukowy.pl/\%C5\%81okie\%C4\%87_(miara) (dostęp: 23 maja 2019); zob. także M. Kozera, Łokieć jako miara dtugości w średniowieczu, „Problemy” 1988, nr 2.

67 To jest powodujące krwawienie na „obliczu”, czyli twarzy poszkodowanego.

68 Wywołujące jakiekolwiek krwawienie, za wyjątkiem twarzy zranionego.

69 Skutkujące zasinieniem, jednak nie otwartą, krwawiącą raną.

Prawo 328, 2019

(C) for this edition by CNS 
nio w wysokości: 30 grzywien, 20 grzywien oraz sześciu groszy ${ }^{70}$. Ten sam przepis przewiduje także kary dla sprawców ochromienia ${ }^{71}$, o ile okaleczenie spowodowało trwałą nieprzemijającą niesprawność dolnej lub górnej kończyny lub oślepienie oka albo odcięcie nosa. Kara pieniężna za takie przestępstwo miała stanowić połowę główszczyzny. Osobno potraktowano odcięcie palca, za które przewidziano 20 grzywien. Ponadto postanowiono, że każda rana lub okaleczenie powinny być karane podwójnie (czyli dwukrotnością przewidzianej zasadniczo kary pieniężnej), jeżeli sprawca czynu swego dokonał przy użyciu broni palnej ${ }^{72}$.

Petryfikowany w sejmowej konstytucji z 1588 roku stan prawny co do zbrodni mężobójstwa i sposobu ścigania tego przestępstwa zasadniczo przetrwał do upadku Rzeczypospolitej u schyłku XVIII wieku. Idea państwa, która w Polsce XVI wieku na tylu polach święciła chwile swoich pięknych zdobyczy, w walce $\mathrm{z}$ dawnym zwyczajem okazała się bezsilna ${ }^{73}$. Nota bene trwałość karnoprawnych postanowień konstytucji sejmu koronacyjnego z 1588 roku nie dotyczyła li tylko zbrodni zabójstwa. Wiele spośród omawianych jej przepisów, będących w znacznym zakresie utrwaleniem dotychczasowych, często zwyczajowych zasad prawnych, obowiązywała aż ko końca istnienia państwa polsko-litewskiego. Potwierdza to tezę o zachowawczości czy wręcz wyjątkowym konserwatyzmie dawnego polskiego prawa.

\section{Bibliografia}

\section{Źródła drukowane i rękopiśmiennicze}

Constitutiones in Conventi Generali Cracoviensi. Anno 1539, Biblioteka Zakładu Narodowego im.

Ossolińskich Polskiej Akademii Nauk we Wrocławiu, 1048/II.

Corpus Iuris Polonici, sec. 1, vol. 3 Annos 1506-1522, wyd. O. Balzer, Kraków 1906.

70 „Rany szlacheckie mają być sowicie płacone: to iest, krwawa, grzywien dwadzieścia, a sina groszy sześć, z winą sądową: a obliczna rana znaczna krwawa grzywien trzydzieści [...]”; VL, t. 2, s. 255. Grzywną, o której mowa w sejmowej konstytucji, jest zapewne tak zwana grzywna krakowska równoważna 48 groszom praskim; https://pl.wikipedia.org/wiki/Grzywna_krakowska (dostęp: 23 maja 2019). Groszem jest najpewniej tak zwany grosz krakowski, srebrna moneta polska, wprowadzona przez Kazimierza Wielkiego w 1367 roku, wzorowana ściśle na groszu praskim zarówno co do wartości, jak i typologii; https://pl.wikipedia.org/wiki/Grosz_krakowski (dostęp: 23 maja 2019); http://www.historiapieniadza.pl/wp/?page_id=50 (dostęp: 23 maja 2019). Szerzej na ten temat zob. A. Dylewski, Historia pieniadza na ziemiach polskich, Warszawa 2011, s. 319.

71 Stp. okaleczenie.

72 „A chromota wieczna na ręce nodze y oślepienie oka, także ucięcie nosa ma być płacone, iako połowica głowy wedle teraźnieyszey konstytucyi. A rana każda z ruśnice in duplo płacona być ma"; ibidem.

73 A. Pawiński, O pojednaniu..., s. 67.

Prawo 328, 2019

(C) for this edition by CNS 
Gloger Z., Encyklopedia staropolska, t. 3, Warszawa 1902.

Kaptur betski zaraz po śmierci królewskiej uczyniony, AGAD, APP 6.

Konfederacja województwa betskiego, Bełz 31 grudnia 1586, Biblioteka Zakładu Narodowego im. Ossolińskich Polskiej Akademii Nauk we Wrocławiu 15964/ II.

Oblata kaptura betskiego, Biblioteka Muzeum Narodowego im. Czartoryskich w Krakowie, 2723. Ostrowski T., Prawo cywilne narodu polskiego, t. 1, cz. 4. O przestępstwach i karach, Warszawa 1787. Radziwiłł A.S., Pamiętnik, t. 1, Warszawa 1980.

Sobieski W., Trybun ludu szlacheckiego. Pisma historyczne, Warszawa 1978.

Volumina Constitutionum, t. 1. 1493-1549, vol. 1. 1493-1526, do dr. przygot. S. Grodziski, I. Dwornicka, W. Uruszczak, Warszawa 1996.

Volumina Constitutionum, t. 1. 1493-1549, vol. 2. 1527-1549, do dr. przygot. S. Grodziski, I. Dwornicka, W. Uruszczak, Warszawa 2000.

Volumina Constitutionum, t. 2 1550-1609, vol. 1. 1550-1585, do dr. przygot. S. Grodziski, I. Dwornicka, W. Uruszczak Warszawa 2005.

Volumina Constitutionum, t. 2. 1550-1609, vol. 2. 1587-1609, do dr. przygot. S. Grodziski, W. Uruszczak, Warszawa 2008.

Volumina Legum. Przedruk Zbioru Praw staraniem xx. pijarów w Warszawie od roku 1732 do roku 1782 wydanego, t. 1, Petersburg 1859.

Volumina Legum. Przedruk Zbioru Praw staraniem xx. pijarów w Warszawie od roku 1732 do roku 1782 wydanego, t. 2, Petersburg 1859.

Zalaszowski M., Ius Regni Poloniae, t. 1-2, Poznań 1701-1702.

\section{Akty normatywne}

Actum Piotrcoviae in conventu generali regni, 22 Februarii a. 1510, Corpus Iuris Polonici, sec. 1, vol. 3.

Constitutiones in Conventi Generali Cracoviensi a. 1539, Volumina Legum, t. 1.

Decreta conventus generalis regni, 4 Decembris a. 1520, Corpus Iuris Polonici, sec. 1, vol. 3.

Konstytucje sejmu piotrkowskiego 1565 roku; Volumina Constitutionum, t. 2, vol. 1.

Konstytucye Seymu Walnego, Koronacyi Krolewskiey, Roku Bożego 1588, Volumina Costitutionum, t. 2, vol. 2; Volumina Legum, t. 2.

\section{Literatura}

Balzer O., Początki sądów kapturowych, „Ateneum. Pismo naukowe i literackie” 2, 1885.

Bieda J., Cele i organizacja zakładów karnych w I Rzeczypospolitej, „Acta Universitatis Lodziensis. Folia Historica" 94, 2015.

Czerwiec M., Więzienioznawstwo. Zarys rozwoju więziennictwa, Warszawa 1958.

Dąbkowski P., Jeszcze o odpowiedzi w prawie polskiem, Lwów 1899.

Dąbkowski P., Zasada jawności w dawnem prawie polskiem, „Przewodnik Historyczno-Prawny” $5,1937$.

Dubas-Urwanowicz E., Bezkrólewie - czas integracji, czy podziałów, „Przegląd Historyczny” 85, 1994, nr 1-2.

Dyjakowska M., Crimen laesae maiestatis. Studium nad wptywami prawa rzymskiego w dawnej Polsce, Lublin 2010.

Dyjakowska M., Crimen laesae maiestatis jako przykład wpływów prawa rzymskiego na prawo Polski przedrozbiorowej. Stan badań i postulaty, [w:] Wspótczesna romanistyka prawnicza w Polsce, red. A. Dębiński, M. Wójcik, Lublin 2004. 
Dyjakowska M., Subsydiarne stosowanie prawa rzymskiego w Polsce przedrozbiorowej na przyktadzie zbrodni obrazy majestatu, „Teka Komisji Prawniczej OL PAN” 5, 2012.

Dylewski A., Historia pieniadza na ziemiach polskich, Warszawa 2011.

Konopczyński W., Chronologia sejmów polskich 1493-1793, Kraków 1948.

Kozera M., Łokieć jako miara długości w średniowieczu, „Problemy” 1988, nr 2.

Kutrzeba S., Dawne polskie prawo sądowe w zarysie, Lwów-Warszawa-Kraków 1927.

Kutrzeba S., Mężobójstwo w prawie polskiem w XVI stuleciu, Kraków 1929.

Kutrzeba S., Pojedynki w Polsce, Kraków 1909.

Lityński A., Przestępstwa polityczne w polskim prawie karnym XVI-XVIII wieku, Katowice 1976.

Łopatecki K., Organizacja, prawo i dyscyplina w polskim i litewskim pospolitym ruszeniu, Białystok 2018.

Makarewicz J., Polskie prawo karne, Lwów-Warszawa 1919.

Makiłła D., Próba reformy sądownictwa powszechnego z czasów bezkrólewia po ucieczce króla Henryka Walezego (1574), „Miscellanea Historico-Iuridica” 14, 2015, z. 2.

Naworski Z., Dobra sława i cześć w aktach sadowych dawnej polski, [w:] Honor, cześć, godność. Aspekty historyczno-prawne, red. P. Wiązek, Wrocław 2016.

Opaliński E., Elekcje wazowskie w Polsce. Stosunek szlachty do instytucji okresu bezkrólewia, „Kwartalnik Historyczny” 92, 1985, nr 3.

Pawiński A., O pojednaniu w zabójstwie wedlug dawnego prawa polskiego, Warszawa 1884.

Pawlak K., Za kratami więzień i drutami obozów, Kalisz 1999.

Pieńkowska A., Zjazdy i sejmy z okresu bezkrólewia po śmierci Stefana Batorego, Pułtusk 2010.

Rabinowicz L., Podstawy nauki o więziennictwie, Warszawa 1933.

Rafacz J., Dawne polskie prawo karne, część ogólna, Warszawa 1932.

Wałęga S., System penitencjarny w dawnym Toruniu (do końca XVIII w.), „Rocznik Toruński” 17, 1986.

Wąsowicz J., Rola polskiego modelu tolerancji religijnej dla hugenotów francuskich, „Seminare. Poszukiwania naukowe" 15, 1999.

Widacki J., Szkice z dziejów prawa karnego i kryminologii w Krakowie myśli i ludzie, Kraków 2014. Zgoliński I., Zniestawienie w polskim prawie karnym. Zagadnienia teorii i praktyki, Warszawa 2013.

\section{Źródła internetowe}

http://encyklopedia.naukowy.pl/\%C5\%81okie\%C4\%87_(miara) (dostęp: 23 maja 2019).

https://encyklopedia.pwn.pl/haslo/egzorbitancje;3896776.html (dostęp: 3 lutego 2019).

http://www.historiapieniadza.pl/wp/?page_id=50 (dostęp: 23 maja 2019).

https://pl.wikipedia.org/wiki/\%C5\%81okie\%C4\%87_(miara) (dostęp: 23 maja 2019).

https://pl.wikipedia.org/wiki/Grzywna_krakowska (dostęp: 23 maja 2019).

https://pl.wikipedia.org/wiki/Grosz_krakowski (dostęp: 23 maja 2019).

\section{Criminal law in the constitutions of the Coronation Sejm of 1588}

Summary

The author attempts to select and then to analyse criminal law provisions of the constitutions of the Coronation Sejm of 1588. Using a dogmatic-linguistic interpretation, applied together with the historical-descriptive method, he seeks to present the results of his explorations in a broad historical perspective. His intention is to illustrate the evolution of some institutions of Polish criminal law 
in the past. Drawing on comparative legal research, he presents the results of his studies in a broad historical-legal perspective. The author ends with confronting his final conclusions with theses formulated by some other, outstanding scholars, hoping that his research will inspire other explorers of the subject matter.

Keywords: history of law, criminal law, evolution of the court of law, criminal liability, Polish parliamentary legislation in the past

\section{Das Strafrecht in den Verfassungen des Krönungssejm aus dem Jahre 1588}

\section{Zusammenfassung}

Der Autor des Artikels versuchte die strafrechtlichen Bestimmungen der Verfassung des Krönungssejm aus dem Jahre 1588 auszuwählen und dann zu analysieren. Unter Verwendung der sprachlich-dogmatischen Auslegungsmethode und subsidiär der deskriptiv-historischen, bemühte er sich, die Ergebnisse seiner Untersuchung vor einer breiten historischen Perspektive darzustellen. Seine Intention war, den Prozess der Evolution einiger Institutionen des alten, polnischen Kriminalrechtes zu schildern. Mit Hilfe der rechtlichen Komparatistik wollte er die Ergebnisse der durchgeführten Forschung aus einem breiten rechtshistorischen Blickwinkel darstellen. Die zum Schluss der Forschungsarbeit formulierten Einsichten, die mit Thesen anderer Berühmtheiten konfrontiert werden, sollten weitere Forscher für die vorgenommene Problematik gewinnen.

Schlüsselworte: Rechtsgeschichte, Strafrecht, Evolution des Gerichtsrechts, strafrechtliche Verantwortung, Gesetzgebung des alten polnischen Sejm 